\title{
Uma abordagem reducionista ao problema da identidade dos indiscerniveis ${ }^{1}$
}

\author{
João Faria e Silva \\ UNIVERSIDADE DO PORTO
}

\section{RESUMO}

Pretendo defender a tese de que a verdade de qualquer proposição acerca do número de particulares existentes no mundo é superveniente a partir da verdade de todas as proposições exclusivamente acerca de universais (i.e., propriedades e relações). Se esta tese estiver correta, todos os factos acerca da individuação dos particulares são redutíveis a factos exclusivamente acerca de universais, não havendo individuação primitiva de particulares. Apresento dois argumentos contra a possibilidade de individuação primitiva. $O$ primeiro é que os particulares primitivamente individuados levantam dúvidas céticas radicais acerca do número de particulares com que nos confrontamos. $\mathrm{O}$ segundo é que os particulares primitivamente individuados são teoricamente redundantes, já que o carácter qualitativo de qualquer mundo possível pode ser exaustivamente descrito falando apenas de universais. A teoria aglomeracionista clássica é a variedade mais comum de reducionismo acerca do número de particulares, mas pretendo defender também que esta não é a única variedade possível. Mais concretamente, apresento uma alternativa segundo a qual os particulares são individuados por relações espaciais. Esta alternativa, contrariamente à teoria aglomeracionista, não nos compromete com o controverso princípio da identidade dos indiscerníveis, mas implica uma conceção transcendente de universais.

Palavras-chave: particulares; universais; identidade numérica; individuação; reducionismo; teoria aglomeracionista; princípio da identidade dos indiscerníveis.

1 A investigação que resultou na produção deste texto foi financiada pela Fundação para a Ciência e a Tecnologia (Referência da Bolsa: 2020.05192.BD). 
João Faria e Silva, 'Uma abordagem reducionista ao problema da identidade dos indiscerníveis', Linguagem e ontologia: questões sobre conhecimento e agência / Language and Ontology:

Questions on Knowledge and Agency, Porto, FLUP, 2021, pp. 43-80, https://doi.org/10.21747/978-989-9082-05-2/ofaa4.

\begin{abstract}
I aim to defend the thesis that the truth of any proposition about the number of particulars that exist in the world is supervenient upon the truth of all propositions exclusively about universals (i.e., properties and relations). If this thesis is correct, all facts about the individuation of particulars are reducible to facts exclusively about universals, and there is no primitive individuation of particulars. I present two arguments against the possibility of this kind of primitive individuation. The first is that the possibility of primitively individuated particulars raises radical skeptical doubts about the number of particulars with which we are acquainted. The second is that primitively individuated particulars are theoretically redundant since the qualitative character of any possible world can be exhaustively described if we talk only about universals. The classical bundle theory is the most common variety of reductionism about the number of particulars, but I also want to defend that it is not the only possible variety. More specifically, I present an alternative according to which particulars are individuated by spatial relations. This alternative, in contrast to bundle theory, does not commit us to the controversial principle of the identity of indiscernibles, but it implies a transcendent conception of universals.
\end{abstract}

Keywords: particulars; universals; numerical identity; individuation; reductionism; bundle theory; principle of the identity of indiscernibles.

\title{
1-Introdução
}

DE ACORDo com a tese que pretendo defender, o número de particulares que compõem o mundo é superveniente a partir da totalidade de factos unicamente acerca de universais, ou, por outras palavras, não pode haver nenhuma diferença no número de particulares existentes sem haver também alguma diferença naquilo que é verdade apenas acerca de universais. Assumindo, como farei na discussão que se segue, que a realidade está, pelo menos a um nível básico ou primitivo, dividida exaustivamente em particulares e universais (entendendo estes últimos como propriedades e relações qualitativas ${ }^{2}$ ), negar esta

2 Portanto, não pretendo classificar as propriedades e relações não-qualitativas como universais, mesmo aquelas que podem ser instanciadas por várias coisas ou várias sequências de coisas. A propriedade de estar a dois metros da Torre Eiffel, por exemplo, pode ser instanciada por várias coisas, mas é uma propriedade não-qualitativa que pressupõe a existência da Torre Eiffel para ser instanciada e, desse modo, não será contada como um universal. 
tese, à qual chamo reducionismo acerca do número de particulares, é o mesmo que aceitar a possibilidade de existirem particulares primitivamente individuados (ou, de maneira abreviada, particulares primitivos). Basicamente, as entidades de uma categoria ontológica são primitivas quando o número de entidades pertencentes a essa categoria não é superveniente a partir de factos unicamente acerca de entidades de outras categorias.

Os particulares primitivos, para quem rejeitar o reducionismo acerca do número de particulares, podem ser os próprios particulares concretos, como moléculas, pedras, artefactos, plantas, animais e pessoas, ou entidades menos familiares para a nossa teoria popular do mundo, como particulares nus, tropos ou particulares abstratos e pontos ou regiões do espaço-tempo, os quais podem eventualmente ser usados para explicar a existência dos particulares concretos e a diferença numérica entre eles. Em todo o caso, daqui em diante vou assumir que, a par dos universais, existem apenas particulares concretos. Esta suposição permite-me simplificar a discussão e não tem importantes consequências, já que, creio, os argumentos que vou apresentar contra a existência de particulares concretos primitivos também se aplicam à existência de particulares nus, tropos ou particulares abstratos ou pontos e regiões do espaço-tempo, pelo menos se estes forem entendidos como primitivamente individuados.

Alguns autores parecem assumir que negar a possibilidade de particulares primitivos implica aceitar a verdade necessária do controverso princípio da identidade dos indiscerníveis. Adiante, depois de defender o reducionismo acerca do número de particulares, pretendo mostrar também que essa implicação é ilusória.

Convém distinguir o reducionismo acerca do número de particulares de uma tese reducionista mais forte, de acordo com a qual todas as verdades acerca de particulares são supervenientes a partir da totalidade de verdades unicamente acerca de universais. Ao contrário do que acontece na primeira tese, nesta última não é apenas a existência dos particulares e a diferença numérica entre eles que é superveniente a partir dos factos relativos a universais, mas também a natureza qualitativa dos particulares, a qual envolve quer a maneira como cada particular é em si mesmo, intrinsecamente, quer 
a maneira como se relaciona com as restantes coisas. É natural que um defensor da primeira tese defenda também esta última. Na verdade, perto do final do artigo esboço uma proposta acerca da individuação dos particulares que implica esta tese mais forte. No entanto, encontro apenas problemas mais ou menos evidentes na negação do reducionismo acerca do número de particulares e não com a negação do reducionismo mais geral. Desse modo, considero conveniente ter em mente a distinção entre as duas teses ${ }^{3}$.

\section{2 - As verdades acerca de universais}

De acordo com uma proposta de James Van Cleve (1985), algumas verdades unicamente acerca de universais apenas podem ser expressas por frases com uma forma lógica diferente daquela que apresentam as frases da linguagem comum e das linguagens formais até hoje criadas, exigindo, para a sua expressão, a introdução de um novo operador lógico:

Uma linguagem apropriada a esta ontologia consistiria simplesmente em nomes de propriedades juntamente com um sinal para a instanciação, por exemplo um ponto de exclamação. Em vez de ' $\exists x(F x)$ ', que sugere que há alguma coisa que instancia $F$, poderíamos ter '! $(F)^{\prime}$ ' ( $F$ é instanciada); em vez de ' $\exists x(F x \& G x)$ ' poderíamos ter '! $(F G)$ ' ( $F$ é coinstanciada $\operatorname{com} G)$, e em vez de ' $\exists x \exists y(F x \& F y \& \sim(x=y))$ ' poderíamos ter '!!(F)' ( $F$ é instanciada pelo menos duas vezes). Esta notação realça o facto de que apesar de as propriedades serem instanciadas, elas não são instanciadas por nada - nem mesmo por aglomerados de propriedades.

(Van Cleve 1985:104)

3 Todas as citações contidas neste artigo foram escritas originalmente em inglês e traduzidas por mim para português. 
A intenção de J. Van Cleve era encontrar paráfrases das várias afirmações sobre particulares que não nos comprometessem com a existência de nada mais para além de universais. Para esse efeito, considerou que precisaríamos de falar não apenas das propriedades que os universais instanciam, bem como das relações que entre eles estabelecem, mas também, e principalmente, da instanciação dos próprios universais, sendo que, aparentemente, falar acerca da instanciação de universais exige a introdução de um novo operador lógico que está completamente ausente do discurso habitual sobre particulares e universais.

Seria bastante simples argumentar a favor do reducionismo acerca do número de particulares se aceitássemos que algumas das frases construídas com este novo operador expressam verdades unicamente acerca de universais. A cada um dos particulares existentes corresponderia uma frase com a forma lógica '!(...)', devendo '...' ser preenchido por termos que referem os universais instanciados pelo particular. Contar os particulares a partir das verdades acerca de universais expressas desta forma só não seria adequado se existissem particulares indiscerníveis. Mas, para resolver isso, teríamos verdades expressas por frases das formas '!!(...)', '!!!(...)', e por aí adiante, o que nos permitiria diferenciar numericamente os particulares indiscerníveis.

Contudo, eu rejeito esta linha argumentativa, já que o operador lógico de instanciação, a meu ver, ou não é inteligível ou é inadequado para os propósitos deste argumento. Estas são as possibilidades que encontro de interpretar o operador:

(1) Existe uma hierarquia de universais. Os universais de primeira ordem, como a retangularidade ou a coragem, apenas podem ser instanciados por particulares. Os universais de segunda ordem podem ser instanciados por universais de primeira ordem ou por particulares. Em geral, os universais de um certo nível apenas podem ser instanciados por universais de níveis inferiores ou por particulares. A relação de semelhança parece ser um universal de segunda ordem, ou até mesmo de uma ordem ainda mais elevada. Numa ontologia como aquela com que estamos a lidar, em que é pretendido falar de instanciação sem falar imediatamente de particulares, a instanciação é problemática 
quando não se trata da instanciação de um universal por um outro universal de ordem inferior. Nos casos problemáticos, a instanciação de um universal pode ser entendida como uma propriedade de ordem superior. Contudo, se for adequada, a noção de instanciação não serve os propósitos para os quais foi introduzida. Um desses propósitos é poder falar-se em universais instanciados em conjunto. O que significa dizer que certos universais são instanciados em conjunto? Não pode querer dizer que esses universais têm em comum uma certa propriedade, porque isso não permite estabelecer qualquer diferença entre esses universais serem todos instanciados e todos eles serem instanciados em conjunto. Não há nada que seja ter a mesma propriedade em conjunto. Parece que aqui estamos a falar de uma relação e não de uma propriedade, uma relação que, para acomodar os casos em que se fala da instanciação de um único universal, pode relacionar um universal consigo mesmo. Mas esta manobra também não resolve os problemas, porque, além disso, pretende-se que os universais possam ser instanciados mais do que uma vez. Mas o que significa dizer que os universais são instanciados duas vezes, três vezes, e por aí adiante? Não pode querer dizer nem que eles têm uma certa propriedade duas vezes, três vezes, e por aí adiante, nem que eles estabelecem uma certa relação duas vezes, três vezes, e por aí adiante. Até pode fazer sentido falar-se da quantidade de vezes que uma coisa tem uma certa propriedade ou uma sequência de coisas estabelece uma relação, mas apenas se estivermos a falar das vezes em que isso ocorre ao longo de um período de tempo. Aqui, no entanto, pretende-se admitir também a instanciação múltipla num único momento.

(2) Dizer que um universal é instanciado é o mesmo que dizer que há coisas que o instanciam; dizer que dois universais são instanciados conjuntamente é o mesmo que dizer que existe uma coisa que instancia ambos os universais; e dizer que um universal é instanciado duas vezes é dizer que existem duas coisas numericamente distintas que o instanciam. Esta explicação da noção de instanciação é perfeitamente inteligível. No entanto, se esta explicação for adequada, dizer que certos universais são instanciados implica falar de particulares. Isto porque alguns universais apenas podem ser instanciados por particulares e nunca por outros universais. A propriedade de ser retangular é um 
exemplo disso. Dizer que a retangularidade é instanciada é dizer que há um particular que é retangular. Ora, a introdução do operador lógico de instanciação tinha como propósito precisamente permitir-nos falar da instanciação de universais sem falar imediatamente de particulares.

(3) Dizer que um universal é instanciado é dizer que há um tropo que é uma instância desse universal; dizer que dois universais são instanciados conjuntamente é dizer que há tropos que são instâncias desses universais e estabelecem entre si alguma relação adequada; e dizer que um universal é instanciado duas vezes é dizer que há dois tropos que são instâncias desse universal. Esta explicação também é inteligível tanto quanto o é a noção de tropo. Tem, no entanto, o mesmo problema que a explicação anterior. Falar de tropos é estar já a falar de particulares.

(4) Na conceção imanente de universais, um universal encontra-se integralmente em cada região espaciotemporal onde se encontra uma coisa que o instancia. Não pretendendo falar de coisas que instanciam universais, porque vimos que em alguns casos isso implica falar imediatamente de particulares, podemos ainda assim dizer que um universal é instanciado se estiver numa região espaciotemporal, dois universais são instanciados conjuntamente se estiverem na mesma região espaciotemporal; e um universal é instanciado duas vezes, três vezes, e por aí adiante, se estiver integralmente em duas, três, ou mais regiões espaciotemporais. Desta forma, a noção de instanciação poderia ser analisada em termos da localização espaciotemporal de universais. No entanto, se dizer que um universal está localizado numa certa região espaciotemporal é dizer que existem pontos do espaço-tempo ocupados pelo universal, tal discurso envolve já um compromisso com particulares, mais precisamente os pontos do espaço-tempo.

(5) Dizer que um universal é instanciado é dizer que esse universal faz parte de um aglomerado de universais adequadamente relacionados; dizer que dois universais são instanciados conjuntamente é dizer que ambos fazem parte de um mesmo aglomerado de universais adequadamente relacionados; e dizer que um universal é instanciado duas vezes é dizer que faz parte de dois aglomerados de universais adequadamente relacionados. Esta é, em menor detalhe, a análise da 
noção de instanciação oferecida pela teoria aglomeracionista clássica. Esta explicação parece perfeitamente inteligível, pelo menos se admitirmos a inteligibilidade de uma relação que cumpre o papel de unificar universais em aglomerados. Esta proposta, no entanto, não é adequada para lidar com a possibilidade de particulares indiscerníveis, como veremos mais à frente.

(6) O operador lógico de instanciação introduzido por J. Van Cleve expressa uma noção primitiva, que não pode ser explicada de maneira nenhuma recorrendo a outras noções mais básicas. $O$ máximo que se pode fazer é apontar para exemplos de instanciação - singular, conjunta e múltipla - ou, como faz J. Van Cleve, apelar a uma analogia entre a instanciação e a quantificação existencial. Creio que, mesmo assim, seria legítimo afirmar que simplesmente não compreendo essa noção primitiva. Primeiro, não tenho a certeza de que a mostragem de exemplos seja realmente útil. É perfeitamente defensável dizer que compreender o que se passa num cenário que possa servir como exemplo de instanciação envolve necessariamente a compreensão da noção de particular. Mostram-nos uma bola vermelha dizendo 'É nisto que consiste o vermelho ser instanciado'. Mostram-nos de seguida duas bolas vermelhas dizendo 'É nisto que consiste o vermelho ser instanciado pelo menos duas vezes'. Ficamos a perceber a noção de instanciação quando somos confrontados com essas bolas vermelhas? Creio que ficaríamos a compreender que o facto de o vermelho ser instanciado consiste no facto de haver uma coisa vermelha, e que o facto de o vermelho ser instanciado pelo menos duas vezes consiste no facto de haver pelo menos duas coisas vermelhas. Mas compreender a existência de uma ou duas coisas vermelhas envolve compreender a noção de particular. Segundo, quando utilizamos a quantificação existencial para dizer que uma propriedade ou relação é instanciada duas vezes, três vezes, e por aí adiante, utilizamos também a noção de identidade, aplicada diretamente a coisas que instanciam propriedades e relações. Na ontologia com que estamos a lidar, no entanto, não há nada a que possamos aplicar dessa forma a noção de identidade. Não há nenhum mecanismo de, nesta ontologia, afirmar que uma propriedade ou relação é instanciada duas vezes, três vezes, e por aí adiante, de uma maneira análoga àquela em 
que recorremos ao quantificador existencial e ao conceito de identidade para dizer isso. A analogia entre a quantificação existencial e a instanciação é, a certa altura, misteriosa e talvez completamente incompreensível.

\section{3-A teoria aglomeracionista clássica}

As ontologias constituintes são ontologias policategoriais (i.e., que incluem entidades pertencentes a várias categorias) que tratam os particulares concretos como entidades ontologicamente estruturadas, compostas por entidades ainda mais básicas. É importante termos em mente que a estrutura ontológica de um particular concreto não é idêntica à sua estrutura mereológica ou física. A estrutura ontológica de uma molécula de butano, por exemplo, não é a maneira como se relacionam os vários átomos que dela fazem parte. Até possíveis partículas simples, que não podem ser decompostas em partículas ainda mais simples, têm, numa perspetiva deste género, uma estrutura ontológica complexa. De maneira a evitar qualquer ambiguidade, é comum traçar uma distinção entre constituintes e partes (cf. Loux 2006:86). As partículas simples minúsculas não têm partes, apenas constituintes. Átomos de carbono são partes, e não constituintes, de moléculas de butano. Esta parece-me uma maneira adequada de pelo menos parcialmente distinguir as estruturas mereológica e ontológica e, com base nessa distinção, definir os conceitos de constituinte e parte, como explica Peter van Inwagen (2011):

Digamos que especificar a estrutura mereológica de um particular comum (substância, indivíduo, coisa concreta) é especificar os outros particulares comuns, caso existam, que são as suas partes no sentido estrito e mereológico - dizendo que outros particulares estabelecem com ele a relação parte-todo - , e talvez dizendo alguma coisa acerca de como os outros particulares comuns se relacionam entre si no que diz respeito a certas relações que se pensa serem 'relevantes para a estrutura' (relações especiais, talvez, 
João Faria e Silva, 'Uma abordagem reducionista ao problema da identidade dos indiscerníveis', Linguagem e ontologia: questões sobre conhecimento e agência / Language and Ontology:

Questions on Knowledge and Agency, Porto, FLUP, 2021, pp. 43-80, https://doi.org/10.21747/978-989-9082-05-2/ofaa4.

ou relações causais). E digamos que especificar a estrutura ontológica de um particular comum (etc.) é especificar que objetos pertencentes a outras categorias para além da categoria de 'particular concreto' estabelecem com ele uma relação próxima da relação mereológica.

(van Inwagen 2011:390)

Uma das diferenças relevantes entre constituintes e partes é a categoria ontológica a que pertencem. As partes dos particulares concretos são outros particulares concretos mais simples. Os constituintes dos particulares concretos, por sua vez, pertencem necessariamente a outras categorias ontológicas ${ }^{4}$. A estrutura ontológica é conhecida quando decompomos um particular concreto em entidades como universais, tropos ou particulares nus, e não quando isolamos os vários particulares concretos mais pequenos que se encontram espalhados pela região espaciotemporal ocupada por um particular concreto.

A teoria aglomeracionista é um exemplo paradigmático de ontologia constituinte na qual os particulares concretos são tratados como compostos unicamente pelos universais que instanciam. Na variedade clássica desta teoria, os particulares concretos não são mais do que aglomerados de universais copresentes (Russell 1940:cap. 6), e os conceitos de constituinte e aglomerado são identificados, respetivamente, com os conceitos matemáticos de elemento e conjunto, ou pelo menos são entendidos por analogia com estes ${ }^{5}$. A característica

4 Algumas entidades mais básicas que compõem os particulares concretos podem ainda assim ser particulares não-concretos. Em certas ontologias constituintes, cada particular concreto é composto por universais e um particular nu (Allaire 1963). Noutras ainda, os tropos compõem inteiramente os particulares concretos (Williams 1953).

5 Uma alternativa seria explicar as noções de constituinte e aglomerado por analogia com as noções mereológicas de parte e todo. Há, ainda assim, uma diferença relevante entre as relações parte-todo e elemento-conjunto. A relação entre partes e todo é transitiva, contrariamente à relação entre elementos e conjunto. Se $\mathrm{X}$ é parte de $\mathrm{Y}$ e Y é parte de Z, então X é parte de Z. Por sua vez, que A pertence a B e B pertence a $C$ não implica que A pertence a $C$. Esta diferença é relevante para a teoria aglomeracionista porque, admitindo que as noções de constituinte e aglomerado são análogas ou idênticas às noções mereológicas de parte e todo, então, como refere David Lewis, 'não se pode dizer, infelizmente, que um universal é instanciado por qualquer coisa da qual ele é uma parte. Para começar, a relação entre a parte e o todo é transitiva; desse modo, se um universal de carga é parte de uma partícula que é uma parte de um átomo, então o universal é parte 
da relação entre elemento e conjunto que mais nos interessa neste contexto é aquela que é expressa pelo axioma da extensionalidade, de acordo com o qual os conjuntos $\mathrm{X}$ e $\mathrm{Y}$ têm os mesmos elementos se e só se $\mathrm{X}=\mathrm{Y}$. Aplicando este axioma à relação entre constituintes e aglomerados, temos de admitir que a partilha de constituintes implica a identidade numérica entre aglomerados.

A teoria aglomeracionista clássica é, sem dúvida, uma forma de reducionismo acerca do número de particulares. Nesta perspetiva, a existência dos particulares e a diferença numérica entre eles é redutível ao padrão de copresença que os universais apresentam, podendo esse padrão ser completamente descrito sem qualquer referência a particulares. Para o descrever, é necessário apenas especificar que pluralidades de universais estabelecem a relação de copresença. $\mathrm{O}$ axioma da extensionalidade adequa-se às pretensões reducionistas da variedade clássica da teoria aglomeracionista porque permite explicar a identidade dos particulares concretos recorrendo apenas à identidade dos universais por que são compostos. Devido a este axioma, há particulares concretos numericamente diferentes apenas quando houver diferentes pluralidades de universais copresentes.

Mas será a teoria aglomeracionista clássica uma forma de reducionismo geral acerca dos particulares? Será que a teoria aglomeracionista clássica implica que todas as verdades acerca dos particulares são supervenientes a partir da totalidade de verdades unicamente sobre universais? Creio que isso depende da maneira como a teoria é desenvolvida. Se permitir que as propriedades relacionais também sejam constituintes dos particulares, a par das propriedades intrínsecas, então é realmente uma forma de reducionismo geral acerca dos particulares. Nessa hipótese, a copresença dos universais que com-

\footnotetext{
do átomo; mas é a partícula, não o átomo, que instancia o universal. E assim por diante; o universal é parte de tudo, por maior que seja, do qual a partícula é uma parte. Além disso, suponhamos que há todos desunificados compostos por partes variadas, como eu acredito que acontece. Estes podem incluir universais que não instanciam' (Lewis 1986:65). É mais simples dizer que os constituintes de um particular concreto são os universais que instancia do que ter de admitir que, em alguns casos, nem todos os universais que compõem um particular concreto são por ele instanciados. Não sendo isto uma objeção contra a alternativa de conceber mereologicamente os aglomerados, é uma razão para, em alternativa, privilegiarmos a aproximação entre aglomerados e conjuntos.
} 
põem os particulares determina completamente a sua natureza qualitativa, quer intrínseca, quer relacional. Se, pelo contrário, trabalhar apenas com propriedades intrínsecas para construir os particulares, tem ainda de explicar como são estabelecidas as relações externas entre os vários particulares (i.e., aquelas relações que não são supervenientes à natureza intrínseca dos relata, paradigmaticamente as relações espaciotemporais). Uma alternativa seria dizer que as relações externas entre particulares são supervenientes a relações entre universais, dizendo talvez que as próprias relações externas entre os particulares são instanciadas a um nível mais básico entre universais. A distância de dois metros entre duas maçãs, por exemplo, seria então uma relação estabelecida entre essas maçãs em virtude de os universais que compõem uma se encontrarem a dois metros de distância dos universais que compõem a outra. Nos casos em que um mesmo universal é um constituinte comum de dois particulares a uma certa distância, tem de se dizer que estabelece consigo mesmo essa distância. A teoria aglomeracionista assim completada seria também uma forma de reducionismo geral acerca dos particulares.

A situação é diferente, no entanto, se o teórico aglomeracionista pretender defender aquela a que vou chamar a Tese de Allaire ${ }^{6}$ :

As relações - fico-me pelas relações espaciais pressupõem diferença numérica; elas não a explicam. A estidade e a aquelidade das coisas é pressuposta ao dizer-se que uma está à esquerda da outra. Se assim não fosse, então pelo menos em alguns casos teríamos de dizer aquilo que todos sabemos ser falso; nomeadamente, que a mesma coisa está à esquerda de si própria.

(Allaire 1965:19)

A Tese de Allaire afirma que certas relações - paradigmaticamente as relações espaciais - pressupõem a diferença numérica entre os

6 A intenção de Edwin B. Allaire ao defender esta tese era argumentar a favor da existência de particulares primitivos - particulares nus, mais precisamente - capazes de ocupar o papel individuador para o qual nem as propriedades nem as relações eram suficientes. Mas a tese é perfeitamente incorporável na teoria aglomeracionista clássica. 
relata. De acordo com esta tese, se $\mathrm{X}$ está a dois metros de $\mathrm{Y}$, então $\mathrm{X} \neq$ Y. Isto é o mesmo que dizer que nada se encontra integralmente em mais do que uma região espacial ao mesmo tempo, incluindo os universais. Aceitar esta tese implica assim rejeitar também que os universais possam estar a uma certa distância de si próprios. Nesse caso, cai por terra a ideia de que o teórico aglomeracionista pode reduzir todas as relações externas entre particulares a relações externas entre os universais que compõem os particulares. A distância entre duas maçãs que partilham um universal não pode depender de esse universal estabelecer essa distância consigo próprio. Tal distância tem de ser primitivamente estabelecida entre as duas maçãs. A teoria aglomeracionista clássica conjugada com a Tese de Allaire não é uma forma de reducionismo geral acerca dos particulares, porque tem de admitir que alguns aspetos qualitativos dos particulares, pelo menos a maneira como se relacionam espacialmente com outros particulares, não é superveniente a factos unicamente acerca de universais.

Acabámos de ver que o teórico aglomeracionista pode recorrer a propriedades relacionais na construção dos particulares ou restringir-se a propriedades intrínsecas. Porém, a teoria aglomeracionista clássica é provavelmente falsa se não incluir as propriedades relacionais, a par das intrínsecas. É facilmente compreensível que, pelo facto de as noções de constituinte e aglomerado receberem uma interpretação extensional, a teoria aglomeracionista clássica está comprometida com a verdade do princípio da identidade dos indiscerníveis. De acordo com este princípio, para todo o $x$, todo o y e qualquer propriedade $\mathrm{F}$, se $x$ é F se e só se $y$ é $\mathrm{F}$, então $x=y$. Ora, se certos particulares têm as mesmas propriedades, então eles são formados pelos mesmos universais - esses universais são precisamente as propriedades que eles têm em comum. Tendo em conta o axioma da extensionalidade, a partilha dos mesmos constituintes implica a identidade numérica e, ex hypothesi, os universais que instanciam são os únicos constituintes dos particulares. Deste modo, a teoria aglomeracionista clássica tem de admitir que particulares com as mesmas propriedades são numericamente idênticos.

Se os universais que compõem os particulares forem apenas propriedades intrínsecas, a teoria aglomeracionista está comprome- 
João Faria e Silva, 'Uma abordagem reducionista ao problema da identidade dos indiscerníveis',

Linguagem e ontologia: questões sobre conhecimento e agência / Language and Ontology:

Questions on Knowledge and Agency, Porto, FLUP, 2021, pp. 43-80, https://doi.org/10.21747/978-989-9082-05-2/ofaa4.

tida com uma leitura extremamente forte do princípio da identidade dos indiscerníveis, de acordo com a qual a partilha de propriedades intrínsecas implica identidade numérica. Assim lido, o princípio é certamente falso em alguns mundos meramente possíveis e muito provavelmente também no mundo atual. Leia-se, a este respeito, o seguinte:

Acreditamos que, ao nível macroscópico, quaisquer dois objetos, por uma questão de facto, vão exibir alguma diferença interna. Mas é de salientar que a nossa confiança em diferenças no nível macroscópico não se estende aos constituintes microscópicos a partir dos quais (ou assim acreditam os Realistas Científicos acerca das entidades da física) os objetos macroscópicos são feitos. Não pode haver dois eletrões com exatamente as mesmas propriedades não-relacionais?

(Armstrong 1978: 93-94)

O teórico aglomeracionista tem então de admitir que as propriedades relacionais também compõem os particulares. Compromete-se assim com uma leitura mais fraca do princípio da identidade dos indiscerníveis, de acordo com a qual é apenas a partilha de todas as propriedades qualitativas, intrínsecas e relacionais, que implica identidade numérica ${ }^{7}$. É o princípio da identidade dos indiscerníveis,

7 Excluem-se as propriedades não-qualitativas (e.g., a de ser idêntico a Júlio César ou a de estar a quinze quilómetros de Roma). O princípio da identidade dos indiscerníveis lido de maneira a incluir estas propriedades é incontroverso. Obviamente dois particulares $\mathrm{X}$ e Y são diferentes no que diz respeito a alguma propriedade não-qualitativa. $\mathrm{X}$ não tem, como $\mathrm{Y}$, a propriedade de ser idêntico a $\mathrm{Y}$ nem a propriedade de ser distinto de X. Não haveria qualquer problema se a teoria aglomeracionista clássica implicasse apenas esta leitura fraca do princípio. No entanto, isso aconteceria apenas se o teórico aglomeracionista recorresse a propriedades não-qualitativas para construir os particulares. David M. Armstrong (1978:94) considera que esta estratégia é inaceitável dada a pretensão do teórico aglomeracionista de analisar o conceito de particular, que estaria a ser pressuposto nas propriedades não-qualitativas. Parece-me, no entanto, que o teórico aglomeracionista pode não querer analisar o conceito de particular, mas explicar apenas a estrutura ontológica dos particulares. Nesse caso, não é imediatamente descabido dizer que as propriedades não-qualitativas são entidades mais básicas que os particulares, servindo como seus constituintes, apesar de envolverem já o conceito de particular. Em qualquer caso, o resultado disso seria uma teoria com contornos bastante diferentes da teoria aglomeracionista clássica. As propriedades não-qualitativas não são realmente 
assim lido, uma verdade acerca do mundo atual? Parece razoável supor que sim. Aparentemente há sempre alguma propriedade relacional que diferencia várias coisas com a mesma natureza intrínseca. E quanto aos restantes mundos possíveis? Era possível que o princípio da identidade dos indiscerníveis, lido desta maneira, fosse falso? Exemplos como o que se segue parecem mostrar que sim:

\begin{abstract}
Não é possível que o universo contivesse nada mais do que duas esferas perfeitamente semelhantes? Podemos supor que cada uma era feita de ferro quimicamente puro, tinha uma milha de diâmetro, que tinham a mesma temperatura, cor, e por aí adiante, e que nada mais existia. Deste modo, qualquer qualidade e característica relacional de uma seria também uma propriedade da outra. Se aquilo que estou a descrever é logicamente possível, não é impossível que duas coisas tenham todas as suas propriedades em comum.
\end{abstract}

(Black 1952:156)

\begin{abstract}
A possibilidade de mundos simétricos como este que Max Black descreve implica que o princípio da identidade dos indiscerníveis não é necessariamente verdadeiro. A fortiori, a teoria aglomeracionista clássica também não é necessariamente verdadeira. Este é um problema para quem pretender que a ideia básica da teoria aglomeracionista - que os particulares são entidades compostas pelos universais que instanciam - constitua uma análise do conceito de particular e se aplique a qualquer particular possível. Leia-se, como exemplo, o que escreve Gonzalo Rodriguez-Pereyra:
\end{abstract}

a Teoria Aglomeracionista é uma teoria acerca da natureza dos particulares e desse modo deve aplicar-se a todos os particulares em todos os mundos possíveis, não apenas aos particulares atuais. Se há particulares meramente possíveis 
que não são aglomerados de universais, o que os torna particulares? Questões como esta ficam por responder numa versão da Teoria Aglomeracionista que faça apenas uma asserção acerca de particulares atuais.

(Rodiguez-Pereyra 2004:72, nota 2)

A meu ver, a ideia aglomeracionista não tem de ser verdade de qualquer particular meramente possível, essencialmente porque não tem de ser uma teoria acerca do que faz com que necessariamente um particular seja de facto um particular. Pode ser, em vez disso, uma teoria acerca da natureza dos particulares que existem no mundo atual. Albert Casullo $(1984,1988)$ é um importante proponente desta variedade da teoria aglomeracionista, chegando a compará-la com a teoria da identidade em filosofia da mente. Esta teoria afirma que no mundo atual os nossos estados mentais são idênticos a certos estados físicos, reconhecendo, porém, que isto não é verdade noutros mundos possíveis. A teoria da identidade é contingente, essencialmente porque não é uma teoria acerca do que faz com que uma coisa seja um estado mental, mas antes uma hipótese empírica acerca de que coisas são efetivamente estados mentais. Uma abordagem completa ao mental, obviamente, tem de complementar a teoria da identidade com uma análise dos conceitos mentais. Alguns teóricos da identidade (e.g., Lewis 1966) analisam os conceitos mentais como conceitos funcionais, defendendo que é o papel causal a característica que faz com que uma coisa seja classificada como um estado mental. Do mesmo modo, um teórico aglomeracionista pode dizer que no mundo atual os particulares são idênticos a aglomerados de universais, mas que isso é uma verdade contingente, não aplicável a particulares noutros mundos possíveis. Para ter uma abordagem completa aos particulares, o teórico aglomeracionista deve também analisar o conceito de particular, explicando o que faz com que uma coisa seja um particular. Assim que conseguir uma análise satisfatória, parece-me que não é uma objeção forte a esta teoria o facto de não ser aplicável a todos os particulares possíveis.

A proposta aglomeracionista contingente pode ser ou não uma forma de reducionismo acerca do número de particulares, depen- 
dendo da maneira como explica a individuação de particulares indiscerníveis em mundos como aquele descrito por M. Black. Se admitir que a individuação nesses mundos é primitiva, então não é uma forma de reducionismo acerca do número de particulares. No entanto, parece-me difícil imaginar uma explicação da individuação dos particulares nesses mundos que não sirva também para explicar a individuação dos particulares em qualquer outro mundo, incluindo o atual. Que razão há, nesse caso, para defender a atualidade contingente da teoria aglomeracionista clássica, quando há uma teoria necessária, mais simples e uniforme, que a pode adequadamente substituir? Assumo, por isso, que a variedade contingente da teoria aglomeracionista clássica não é uma forma de reducionismo acerca do número de particulares. Até se pode dizer que a teoria é reducionista num sentido mais fraco, implicando a superveniência do número de particulares à totalidade de factos unicamente sobre universais como restrita a certos mundos possíveis com a estrutura ontológica do mundo atual. Em qualquer caso, implica a mera possibilidade de particulares primitivos.

A teoria aglomeracionista clássica, aplicada a todos os particulares possíveis, é a maneira mais óbvia de se defender a tese reducionista acerca do número de particulares. Está comprometida, no entanto, com a verdade necessária do princípio da identidade dos indiscerníveis, que é aparentemente falso em certos mundos como aquele descrito por M. Black. A alternativa de restringir as pretensões aglomeracionistas clássicas ao mundo atual, proposta por A. Casullo, parece-me teoricamente interessante apenas se aceitarmos a possibilidade de particulares primitivos. Tentarei argumentar que esta possibilidade é problemática. É necessário, por isso, encontrar alternativas à teoria aglomeracionista clássica.

Recentemente, G. Rodriguez-Pereyra (2004) propôs uma nova variedade da teoria aglomeracionista que, como a variedade clássica, é uma ontologia constituinte em que os particulares são compostos apenas por universais. Difere, contudo, por rejeitar a identificação dos particulares com aglomerados de universais, pelo menos na conceção extensional de aglomerado. $O$ propósito é conciliar a teoria aglomeracionista com a negação do princípio da identidade 
João Faria e Silva, 'Uma abordagem reducionista ao problema da identidade dos indiscerníveis', Linguagem e ontologia: questões sobre conhecimento e agência / Language and Ontology:

Questions on Knowledge and Agency, Porto, FLUP, 2021, pp. 43-80, https://doi.org/10.21747/978-989-9082-05-2/ofaa4.

dos indiscerníveis. Quando instanciam os mesmos universais, dois particulares não têm de ser numericamente idênticos. Esta é a explicação de G. Rodriguez-Pereyra:

Quando um aglomerado se encontra num lugar, há aí também uma outra entidade, nomeadamente uma instância do aglomerado. A instância é inteiramente constituída pelos universais do aglomerado. Mas a instância e o aglomerado são duas entidades distintas. Contrariamente ao próprio aglomerado, uma instância de um aglomerado não pode estar em mais do que um lugar ao mesmo tempo. Deste modo um aglomerado que está em mais do que um lugar ao mesmo tempo tem mais do que uma instância, uma em cada lugar onde se encontra. Estas instâncias não são idênticas entre si, uma vez que elas estão em diferentes lugares de uma só vez e elas não podem estar em mais do que um lugar ao mesmo tempo. Portanto, este aglomerado de universais inteiramente localizado aqui é o mesmo aglomerado que aquele aglomerado de universais inteiramente localizado ali, mas esta instância do aglomerado aqui do aglomerado em questão não é o mesmo que aquela instância ali do mesmo aglomerado.

Tendo introduzido a distinção entre a instância de um aglomerado e o próprio aglomerado o teórico aglomeracionista afirma que os particulares são instâncias de aglomerados de universais. Portanto, os particulares são inteiramente constituídos de universais sem serem idênticos a aglomerados de universais. Assim, quando um aglomerado de universais tem mais do que uma instância, há alguns particulares numericamente distintos com exatamente os mesmos constituintes.

(Rodriguez-Pereyra 2004:78)

É a nova variedade da teoria aglomeracionista uma forma de reducionismo acerca do número de particulares? A resposta depende da maneira como é explicada a individuação das instâncias dos 
aglomerados $^{8,9}$. Tentarei explorar uma proposta aglomeracionista semelhante a esta, que explica redutivamente a individuação dos particulares, mas na qual a distinção entre aglomerados e instâncias colapsa.

\section{4-A estranheza dos particulares primitivos}

Por que razão devemos rejeitar a possibilidade de existirem particulares primitivamente individuados? A razão mais forte, a meu ver, é que, se não rejeitarmos tal possibilidade, temos de aceitar uma maior quantidade de mundos possíveis do que aquilo que parece aceitável. Entre essa multiplicidade de possibilidades encontram-se mundos possíveis qualitativamente idênticos - e, desse modo, absolutamente indiscerníveis - que diferem quanto ao número de particulares que os compõem. Admitir algumas dessas possibilidades leva-nos a ter de adotar uma atitude cética radical relativamente ao número de particulares com que somos confrontados em várias ocasiões, enquanto admitir a existência de outras parece totalmente supérfluo e fere a preferência de vários teóricos por 'paisagens desertas' (Quine 1948). A opinião de senso comum de que existe apenas um livro no local em que nos encontramos quando entramos num

\footnotetext{
8 Parece haver uma maneira de explicar a individuação das instâncias em conformidade com o reducionismo acerca dos particulares. A ideia é que a individuação de uma instância depende da existência de um aglomerado de universais num certo lugar. Essa não pode, no entanto, ser a explicação de G. Rodriguez-Pereyra. Isto porque, de acordo com ele, por razões mais ou menos complexas, falar apenas de aglomerados de universais em certos lugares não permite distinguir mundos com dois particulares indiscerníveis e mundos com três particulares indiscerníveis. G. Rodriguez-Pereyra (2004:79-80) afirma: 'Então qual é a diferença entre um mundo com um único aglomerado localizado em duas lugares e um mundo com o mesmo aglomerado localizado em três lugares equidistantes? A diferença é que no primeiro mundo o aglomerado tem duas instâncias enquanto no outro tem três instâncias. Alguma coisa existe num mundo sem existir no outro'. Parece evidente que, para G. Rodriguez-Pereyra, a individuação das instâncias é um facto primitivo.

9 Ainda mais recentemente foi proposta uma outra teoria aglomeracionista de acordo com a qual os particulares não são identificados com aglomerados de universais nem com instâncias destes, mas antes com aglomerados de instâncias de universais (Zhang 2018). No entanto, não vou discutir aqui esta proposta.
} 
quarto bem iluminado e vemos apenas um livro em cima de uma mesa, admitindo que nenhum jogo complexo de luzes provoca em nós algum tipo de ilusão de ótica, recomenda que rejeitemos possibilidades do primeiro tipo. A navalha de Ockham, entendida como um princípio de economia ontológica de acordo com o qual devemos evitar postular mais entidades do que aquelas que são estritamente necessárias para explicar um certo conjunto de factos, recomenda que rejeitemos possibilidades do segundo tipo.

Comecemos por considerar o seguinte cenário:

\begin{abstract}
Na minha mesa há aparentemente uma esfera. Mas neste caso há realmente não apenas uma esfera, mas 20 esferas indiscerníveis exatamente no mesmo lugar ao mesmo tempo. Cada uma tem o mesmo tamanho, formato, peso, etc. $\mathrm{Na}$ verdade, todas elas têm também as mesmas partes. Estipulemos que nenhuma das esferas se move e que existem exatamente durante o mesmo período de tempo. Obviamente, estas esferas seriam primitivamente distintas; cada uma das esferas é individuada relativamente às demais simplesmente em virtude do facto de ser distinta de cada uma das outras.
\end{abstract}

(Della Rocca 2005:485-486)

De acordo com Michael Della Rocca, o teórico dos particulares primitivos tem de aceitar a possibilidade deste cenário ${ }^{10}$. Se a individuação é primitiva, não dependendo de factos unicamente acerca de universais, inclusive factos acerca de relações espaciotemporais, há alguma razão válida para negar que possam existir vários particulares indiscerníveis a partilharem os mesmos lugares durante todo

10 Um cenário semelhante já fora apresentado pela personagem do diálogo imaginado por M. Black (1952) que defendia o princípio da identidade dos indiscerníveis: 'Se o princípio fosse falso, o facto de eu conseguir ver apenas duas das tuas mãos não seria uma prova de que tens somente duas. E mesmo que todos os testes concebíveis concordassem com a suposição de que tens duas mãos, podes ter durante todo este tempo três, quatro, ou qualquer número de mãos. Podes ter nove mãos, diferentes entre si e todas elas indistinguíveis da tua mão esquerda, e mais nove mãos todas elas diferentes entre si mas indistinguíveis da tua mão direita. E mesmo que tenhas apenas duas mãos, e mais nenhuma, nem tu nem mais ninguém poderia alguma vez conhecer este facto. Para mim isto é intolerável' (Black 1952:155-156). 
o tempo em que existem? Talvez se pudesse responder que os verdadeiros particulares primitivos são os pontos espaciotemporais, e não os particulares concretos comuns, que são individuados em virtude dos pontos que compõem as regiões que eles ocupam. Assim, em cada região espaciotemporal pode haver no máximo um particular a ocupá-la integralmente. Esta resposta, ainda assim, redireciona apenas o problema, que deixou agora de se prender com os particulares concretos comuns para passar a dizer respeito aos pontos espaciotemporais. Não podem existir também pontos indiscerníveis, compondo regiões indiscerníveis que particulares indiscerníveis vão ocupar? Isso seria praticamente o mesmo que ter vários particulares indiscerníveis a ocuparem a mesma região.

Mas por que razão é inadmissível aceitar a possibilidade deste cenário? Para M. Della Rocca, a resposta é que isso seria um contraexemplo à verdade conceptual de que duas coisas indiscerníveis não ocupam exatamente a mesma região espaciotemporal. Até posso concordar com esta ideia, mas creio que há ainda uma razão mais forte para isso. Admitindo esta possibilidade, que razão temos para excluir a sua atualidade? Se pode haver duas, vinte, mil ou infinitas esferas onde nos parece haver só uma, como podemos estar justificados a acreditar que há efetivamente apenas uma? É assim que chegamos a uma atitude cética radical acerca do número de particulares com que estamos confrontados. A única afirmação que podemos justificadamente fazer, nesta hipótese, é que há pelo menos uma esfera!

$\mathrm{O}$ mundo possível que $\mathrm{M}$. Della Rocca descreve contém vinte esferas com exatamente as mesmas partes"11. É possível argumentar contra a possibilidade deste mundo defendendo que não há coisas distintas com exatamente as mesmas partes, e que, assim, na verdade não podemos ter vinte esferas onde vemos apenas uma. Talvez seja verdadeira essa tese acerca da extensionalidade da relação parte-todo, e talvez não. Creio que a suposição de que as vinte esferas têm

11 Melhor ainda, com as mesmas partes próprias. Mesmo uma soma mereológica de certas coisas conta-se entre as suas partes - impróprias, claro. As vinte esferas partilham as mesmas partes próprias, mas cada uma tem uma parte imprópria que não é parte de nenhuma outra - cada uma delas é parte de si mesma e de mais nenhuma esfera. 
as mesmas partes é completamente supérflua para o nosso propósito. Podemos conceber um mundo possível tão problemático quanto este em que não há a partilha total de partes. Temos apenas de conceber um mundo em que cada parte de uma esfera tem as mesmas características intrínsecas e relacionais que uma parte de cada uma das outras esferas, sendo que em cada esfera as suas partes estão relacionadas exatamente da mesma maneira.

Parece, contudo, que precisamos mesmo de aceitar a possibilidade de particulares primitivos de maneira a acomodar a possibilidade de mundos simétricos como aquele descrito por M. Black. Apesar das consequências desastrosas para as nossas pretensões de conhecer o número de particulares com que somos confrontados numa dada circunstância, a verdade é que, aparentemente, negar a possibilidade particulares primitivamente individuados implica rejeitar a possibilidade de certos mundos simétricos. Isto porque, alegadamente, em mundos simétricos há coisas indiscerníveis numericamente distintas e não há mundos possíveis em que existem coisas indiscerníveis se não houver a possibilidade de particulares primitivamente individuados. Dado que a possibilidade de mundos simétricos é intuitivamente plausível, temos de escolher um de dois males: ou aceitar um ceticismo radical acerca do número de particulares ou rejeitar certas intuições modais que nos levam a admitir certos mundos como possíveis. No entanto, John O'Leary-Hawthorne (1995) encontra uma maneira de conciliar a teoria aglomeracionista clássica e a necessidade do princípio da identidade dos indiscerníveis com a possibilidade de mundos simétricos, argumentando, essencialmente, que o teórico aglomeracionista clássico não tem de aceitar que em mundos simétricos haja coisas indiscerníveis numericamente distintas. J. O'Leary-Hawthorne começa por defender que:

\footnotetext{
Para ser pelo menos prima facie plausível, a teoria aglomeracionista deve trabalhar com aquilo que Armstrong chamou uma conceção 'imanente' de universais em vez de uma conceção 'transcendente'.
}

(O’Leary-Hawthorne 1995:191) 
Basicamente a ideia é que, para serem constituintes dos particulares concretos que se encontram espalhados pelo espaço-tempo, os universais devem estar também no espaço-tempo - devem, mais precisamente, estar no mesmo local em que se encontram os particulares que compõem. Uma das consequências da conceção imanente é que um universal pode estar integralmente em mais do que uma localização e, portanto, a uma certa distância de si próprio. Isto acontece quando um universal é instanciado por várias coisas. Nesse caso, o universal está integralmente presente na região ocupada por cada uma das suas instâncias e, se pelo menos duas delas ocuparem regiões diferentes, estando assim a uma certa distância entre si, o universal vai estar a essa distância de si próprio.

De acordo com J. O'Leary-Hawthorne, as consequências da conceção imanente dos universais também se podem estender àquilo que pode ser verdade acerca dos aglomerados de universais. Nesta hipótese, podemos então ter também um aglomerado de universais integralmente em vários lugares a uma certa distância de si próprio. É fácil compreender como esta ideia permite acomodar a possibilidade de mundos simétricos sem particulares primitivamente individuados. Escreve J. O'Leary-Hawthorne:

$$
\begin{aligned}
& \text { É agora claro em que sentido o teórico aglomeracionista vai } \\
& \text { aceitar a possibilidade na qual Black pensou. Há de facto um } \\
& \text { mundo possível com um aglomerado de universais do tipo } \\
& \text { que compõem aquilo que costumamos chamar 'uma esfera' } \\
& \text { e onde o aglomerado está a cinco pés de si próprio. }
\end{aligned}
$$

(O’Leary-Hawthorne 1995:193-194)

Um mundo possível em que existe apenas um aglomerado de universais a uma certa distância de si próprio é um mundo simétrico, e é também um mundo possível sem particulares primitivos. Deixando de lado por agora a questão de saber se existe mesmo um mundo simétrico com duas esferas indiscerníveis, como M. Black defendeu, aquilo que parece ter sido mostrado por J. O'Leary-Hawthorne é que há um mundo possível simétrico qualitativamente idêntico a esse - eles são indiscerníveis, de facto - em que não há duas esferas 
indiscerníveis e em que, por conseguinte, não há a necessidade de individuação primitiva.

A descoberta de mundos possíveis sem qualquer particular primitivo qualitativamente semelhantes aos mundos possíveis com coisas indiscerníveis é extremamente importante para o debate em torno do reducionismo acerca dos particulares, porque esta descoberta pode, a meu ver, ser uma das premissas cruciais de um argumento contra a possibilidade de particulares primitivos. Comecemos por assumir provisoriamente que (1) há mundos possíveis com vários particulares indiscerníveis e que (2) qualquer mundo possível com vários particulares indiscerníveis contém particulares primitivos. A suposição (1) é aquilo que aparentemente é mostrado pelo mundo possível descrito por M. Black, e creio que (2) é assumido por muitos autores que escreveram acerca deste tema. A suposição (2) decorre da ideia intuitiva de que os particulares indiscerníveis, não podendo ser individuados por alguma diferença ao nível dos universais que instanciam, simplesmente não podem ser individuados em virtude de algum facto unicamente acerca de universais.

A partir de (1) e (2) chegamos à suposição de que (3) há mundos possíveis com particulares primitivos. A minha intenção é negar (3) através de um raciocínio por redução ao absurdo. Para isso, retomo a importante descoberta de J. O'Leary-Hawthorne de que (4) para cada mundo possível $W_{1}$ contendo vários particulares indiscerníveis, existe um outro mundo $W_{2}$ que não contém qualquer particular primitivo e que pode ser completamente descrito recorrendo apenas a universais, sendo $W_{1}$ e W2 qualitativamente idênticos e, por isso, indiscerníveis. Parece-me também adequado defender que (5) por parcimónia, não devemos admitir que haja mundos qualitativamente semelhantes que diferem quanto à sua estrutura ontológica básica. A meu ver, é inaceitável povoar o espaço lógico com diferentes estruturas ontológicas que não refletem qualquer diferença qualitativa. Por economia, devemos evitar multiplicar sem necessidade a postulação de coisas em diferentes categorias ontológicas e a falta de impacto de uma categoria ontológica - neste caso, a dos particulares primitivos - no aspeto qualitativo dos mundos possíveis parece-me uma prova evidente de que a categoria é perfeitamente dispensável. 
De (5), segue-se que (6) não devemos admitir que há mundos possíveis com particulares primitivos e mundos possíveis idênticos a esses sem particulares primitivos - se houver mundos de ambos os tipos, então há mundos indiscerníveis que diferem na estrutura ontológica básica, o que fere evidentemente o princípio de parcimónia expresso em (5). Tendo em conta a suposição (6), a partir de (3) somos levados à suposição de que (7) não há mundos qualitativamente idênticos aos mundos com vários particulares indiscerníveis que não contêm particulares primitivos. No entanto, (3) e (4) conjuntamente implicam a negação de (7). A partir de (3), chegamos então à contradição de que há e não há mundos possíveis qualitativamente idênticos aos mundos com vários particulares indiscerníveis que não contêm particulares primitivos. Chegámos assim a uma redução ao absurdo. Temos de rejeitar a suposição (3). Concluímos, então, que não há mundos possíveis com particulares primitivos. Isto equivale a concluir que é verdadeira a tese de superveniência do número de particulares a factos unicamente acerca de universais.

Recordemos que (3) não era uma das suposições com que tínhamos começado o argumento. Era antes uma suposição derivada das suposições iniciais, (1) e (2). Rejeitando (3), temos de admitir que pelo menos uma dessas suposições iniciais também é falsa. J. O'Leary-Hawthorne propõe a recusa de (1), recomendando ao teórico aglomeracionista clássico abandonar a tentativa de descrever os mundos simétricos apelando à existência de particulares indiscerníveis. Considero que podemos, pelo contrário, defender que esses mundos têm mesmo particulares indiscerníveis e insistir que esses particulares não são primitivamente individuados, como tentarei argumentar na próxima seç̧ão.

Apesar de eu apoiar inteiramente a possibilidade de mundos simétricos sem particulares primitivos, não me parece totalmente evidente que, como afirmou J. O'Leary-Hawthorne, a teoria aglomeracionista, para ser plausível, tenha de recorrer a uma conceção imanente de universais. Tal ideia é, a meu ver, um exemplo de falácia da composição. J. O'Leary-Hawthorne parece pressupor que como os universais compõem os particulares, se os universais não estivessem algures no espaço-tempo, isso teria a consequência absurda de que os particula- 
res também não se encontram no espaço-tempo. Mas é perfeitamente concebível que os universais sejam entidades eternas, sem espacialidade nem temporalidade, e componham mesmo assim os particulares concretos que preenchem o tecido espaciotemporal. Suponhamos que é correta uma perspetiva relacional do espaço-tempo. Estar no espaço-tempo é estar relacionado espaciotemporalmente com outras coisas. Não me parece de modo algum absurdo defender que os universais não estabelecem relações espaciotemporais com nada, e que essas relações são apenas instanciadas pelos particulares concretos compostos a partir dos universais. Suponhamos agora uma perspetiva absolutista do espaço-tempo. Estar no espaço-tempo é ocupar uma região espaciotemporal. Isto envolve estabelecer a relação de ocupação com regiões espaciotemporais. Neste caso, a ideia é precisamente a mesma: não é absurdo dizer que os particulares concretos estabelecem essa relação com as regiões espaciotemporais, sem que isso seja verdade dos universais que os compõem.

\section{5-Duas tentativas de superar a teoria aglomeracionista clássica}

A possibilidade de certos mundos simétricos é muitas vezes considerada uma séria ameaça à tese reducionista acerca do número de particulares. A ideia é que nesses mundos há particulares indiscerníveis e, supõe-se, para haver particulares indiscerníveis tem de haver particulares primitivamente individuados que de alguma maneira expliquem a diferença numérica entre os particulares indiscerníveis. A descoberta de mundos possíveis simétricos sem particulares primitivos qualitativamente semelhantes aos mundos simétricos com particulares indiscerníveis, no entanto, permitiu afastar essa ameaça. Tentei argumentar que, por economia ontológica, devemos abandonar a possibilidade de mundos com particulares primitivos e defender que os mundos possíveis simétricos podem ser completamente descritos recorrendo apenas a universais. Ficou ainda por decidir, no entanto, se (1) recusamos a existência de mundos possíveis com vários particulares indiscerníveis ou (2) identificamos esses mundos com outros 
mundos qualitativamente semelhantes sem particulares primitivos. Ambas as alternativas são formas de reducionismo acerca do número de particulares, mas apenas a primeira é compatível com a teoria aglomeracionista clássica. A primeira alternativa pretende manter a necessidade do princípio da identidade dos indiscerníveis, permitindo que os particulares concretos sejam identificados com aglomerados extensionalmente individuados. Pelo contrário, a segunda alternativa insiste, mesmo aceitando que os particulares têm de ser individuados em virtude de factos unicamente acerca de universais, que o princípio da identidade dos indiscerníveis é falso em alguns mundos possíveis - por exemplo, naqueles mundos simétricos parecidos com aquele que é descrito por $\mathrm{M}$. Black.

Tentando defender a teoria aglomeracionista clássica da ameaça provocada pela possibilidade dos mundos simétricos, J. O'Leary-Hawthorne (1995) opta pela primeira alternativa e recomenda ao teórico aglomeracionista que recuse a existência de mundos com vários particulares indiscerníveis relacionados de uma certa maneira e que fale em vez disso de mundos em que apenas um aglomerado de universais se relaciona consigo próprio da mesma maneira que era suposto os indiscerníveis se relacionarem. Retomando o exemplo de M. Black, em vez de um mundo possível com duas esferas indiscerníveis a um quilómetro de distância uma da outra, o teórico aglomeracionista clássico deve considerar que existe unicamente um mundo possível qualitativamente semelhante a esse com apenas um aglomerado de universais a um quilómetro de distância de si próprio.

No entanto, e apesar da sua simplicidade, esta alternativa vai demasiado contra a nossa opinião comum. Creio, por isso, que não devemos atribuir-lhe uma grande probabilidade sem antes percebermos se existem outras alternativas viáveis. Parece-me evidente que contamos quantos particulares existem pelo menos em parte tendo em conta a sua dispersão no espaço: particulares em lugares diferentes num único momento são, segundo a nossa prática comum de individuação, numericamente distintos. Logo, a nossa teoria popular envolve a negação do princípio da identidade dos indiscerníveis (dada a possibilidade de mundos como aquele que é descrito por $\mathbf{M}$. Black). Deve-se evitar trabalhar com uma teoria metafísica que nos 
obrigue a alterar radicalmente aquilo em que acreditávamos previamente, o que inclui também a maneira como normalmente individuamos as coisas. Havendo uma alternativa teórica disponível que mantenha uma maior porção da nossa opinião comum, esta deverá, a meu ver, ser considerada à partida mais provável.

É necessário, contudo, perceber exatamente o que quer dizer afirmar que há diferença numérica onde quer que haja dispersão ou distância espacial. Consideremos o que escreve Robert M. Adams acerca do exemplo de M. Black:

\begin{abstract}
A razão pela qual se assume que os indiscerníveis nestes universos imaginários não são idênticos não é eles terem diferentes propriedades, mas estarem espacialmente dispersos, espacialmente distantes um do outro. $\mathrm{O}$ axioma acerca da identidade que está a ser usado aqui não é que uma coisa não pode ter e deixar de ter a mesma propriedade, mas que a mesma não pode estar em dois locais de uma só vez - ou seja, não estar espacialmente distante de si própria.
\end{abstract}

(Adams 1979:14)

Essencialmente, R. M. Adams está nesta passagem a defender a Tese de Allaire e a aplicar as consequências dessa tese ao caso particular do mundo descrito por M. Black. A Tese de Allaire, recordemos, é a tese de que as relações espaciais pressupõem diferença numérica entre os relata. Esta tese implica que se há esferas a uma certa distância, então essas esferas, contrariamente ao que é proposto por J. O'Leary-Hawthorne, não podem ser numericamente idênticas. Esta é uma interpretação possível da afirmação de que há diferença numérica onde quer que haja distância espacial. Parece-me, todavia, uma interpretação errada. Creio, como disse antes, que temos intuições acerca da maneira como as relações espaciais implicam diferença numérica, mas essas intuições aplicam-se unicamente a particulares - a coisas como esferas, maçãs e livros - e não a universais. A nossa opinião comum é que se certos universais são instanciados num lugar e há, por isso, nesse lugar um particular a instanciar esses universais, então se os mesmos universais forem instanciados noutro 
lugar, necessariamente há um particular numericamente diferente do anterior que instancia estes universais. Nesta interpretação, a nossa opinião é perfeitamente compatível com a proposta de que um aglomerado de universais está a uma certa distância de si próprio. Implica, no entanto, que esse aglomerado de universais não é um particular que instancia os universais que dele fazem parte - por exemplo, um aglomerado composto pela esfericidade e dureza não é uma esfera dura - e que, onde quer que esse aglomerado se encontre, há um particular que instancia os universais contidos nesse aglomerado e que não se encontra em mais nenhum lugar. Isto é precisamente o que acontece de acordo com a nova variedade da teoria aglomeracionista proposta por G. Rodriguez-Pereyra (2004), a qual defende que há uma instância de um aglomerado de universais em cada lugar em que o aglomerado se encontra, mas as instâncias, ao contrário dos aglomerados, não podem ocorrer repetidamente. A esta altura, sabemos que a copresença de certos universais não é capaz de individuar os particulares compostos por esses universais. Isto porque o mundo possível descrito por M. Black é um mundo que, como admitimos, contém vários particulares compostos exatamente pelos mesmos universais copresentes. É necessário, assim, encontrar outros factos unicamente acerca de universais para explicar a individuação dos particulares, se pretendermos adotar a tese reducionista acerca do número de particulares. Uma estratégia passa por conceber o nosso discurso acerca dos particulares como traduzível num discurso unicamente acerca de universais, explicando que podemos dizer que existe um particular a instanciar estes ou aqueles universais quando esses universais estabelecem a relação de copresença e que existem $n$ particulares com estes ou aqueles universais quando esses universais estabelecem a relação de copresença e cada um estabelece uma relação espacial $n$-ádica consigo mesmo. Esta é a proposta de J. Van Cleve (1985), modificada de maneira a dispensar o operador lógico de instanciação, passando a instanciação a ser entendida como a ocupação de uma região espacial. Nesta perspetiva, a falsidade em alguns mundos possíveis do princípio da identidade dos indiscerníveis decorre do nosso conceito de particular. Como há mundos em que uma pluralidade de universais está a uma distância de si própria, dizemos que nesses mundos há 
particulares indiscerníveis. Todo este discurso acerca dos particulares e a sua diversidade numérica, no entanto, não pode ser levado metafisicamente a sério. Quando dizemos que é verdade isto ou aquilo de certos particulares não estamos realmente a quantificar sobre entidades a que chamamos particulares e a atribuir-lhes certas propriedades ou relações. Estamos, em vez disso, a falar disfarçadamente de universais. Esta falta de seriedade metafísica acerca dos particulares é uma fragilidade desta teoria, como admite J. Van Cleve:

Evita as objeções às versões anteriores ao rejeitar que a nossa ontologia contenha elementos ou complexos de elementos com os quais os indivíduos possam ser identificados. Mas se os indivíduos não são idênticos a nada, então estritamente falando eles não existem. Qualquer indivíduo que queira acreditar na sua própria existência deve, portanto, rejeitar a terceira versão da teoria aglomeracionista.

(Van Cleve 2009:163)

Esta teoria tenta resolver o problema da individuação dos particulares sem recorrer à particularidade primitiva, negando que haja particulares. É uma maneira demasiado fácil de resolver o problema da individuação, mas inaceitável. Se não há, estritamente falando, particulares, então não há pessoas. Quem defender a proposta de traduzir o discurso sobre particulares tem de admitir que, apesar de poder afirmar 'eu existo', realmente, num sentido metafisicamente sério, não existe qualquer coisa com que seja idêntico. Se apelarmos mais uma vez à nossa opinião comum, percebemos que esta teoria tem custos bastante elevados.

Uma outra estratégia, que me parece bastante mais promissora, passa por recuperar a Tese de Allaire, recusando, contrariamente ao próprio E. B. Allaire, que, por pressuporem a diferença numérica entre os relata, as relações espaciais não podem explicar essa diferença numérica. A proposta que pretendo explorar passa por dizer que, pelo contrário, as relações espaciais individuam os relata porque pressupõem a diferença numérica entre eles. Recorrendo à Tese de Allaire, não podemos admitir que se estabeleçam relações 
espaciais entre os universais, nem entre os aglomerados de universais. Admitir isso implicaria admitir a possibilidade de uma coisa estar a uma certa distância de si própria. Assim, primeiro, temos de rejeitar a conceção imanente de universais, defendendo que estes se encontram fora do tempo e do espaço, e, segundo, temos de rejeitar também a formulação de G. Rodriguez-Pereyra da nova teoria aglomeracionista. Não podemos admitir aglomerados de universais que podem ocorrer repetidamente a par das instâncias que apenas podem estar num único lugar. Podemos, pelo contrário, fazer colapsar a distinção entre aglomerados e instâncias, e identificar os particulares concretos diretamente com aglomerados, ainda que, em oposição à teoria aglomeracionista clássica, a noção de aglomerado não possa ser entendida como a noção matemática de conjunto nem como qualquer outra noção extensional.

Esta é, em linhas gerais, a estratégia proposta por Sun Demirli (2010):

O meu projeto geral é unir a teoria aglomeracionista a uma abordagem estrutural à individuação, de acordo com a qual aglomerados são posições em estruturas e são distinguidas pelas relações de distância que estabelecem com as outras posições nas estruturas a que pertencem.

(Demirli 2010:8)

As relações espaciais - relações de distância, como refere S. Demirli, mas, a meu ver, não necessariamente apenas estas - formam, pelo seu padrão de instanciação, uma estrutura complexa que liga pontos numericamente distintos cuja individuação se deve inteiramente ao facto de integrarem essa estrutura. Esses pontos, nesta perspetiva, são aglomerados de universais e instanciam os universais por que são compostos. Aglomerados dos mesmos universais são numericamente distintos por serem diferentes pontos da estrutura espacial que permeia a realidade. Tendo em conta que, assim, os universais que compõem um particular não têm o papel de explicar a sua individuação, não precisamos de admitir as propriedades relacionais como constituintes dos particulares, podendo trabalhar apenas com propriedades intrínsecas. Em suma, esta proposta é a conjunção da ideia 
de que (1) um particular é idêntico a um aglomerado de propriedades intrínsecas, com a ideia de que (2) qualquer relação espacial diádica entre $\mathrm{X}$ e $\mathrm{Y}$ implica que $\mathrm{X} \neq \mathrm{Y}$, qualquer relação espacial triádica entre $X, Y$ e $Z$ implica que $X \neq Y, Y \neq Z$ e $X \neq Z$, e por aí adiante. Assim, nesta perspetiva, os factos acerca de relações espaciais explicam a existência dos particulares e a diferença numérica entre eles e a copresença de certas propriedades intrínsecas explica a natureza intrínseca dos particulares que compõem. Estamos perante uma teoria que implica a forma mais extrema de reducionismo acerca dos particulares, a tese que tenho vindo a chamar reducionismo geral acerca dos particulares.

Contudo, há uma objeção bastante forte a considerar. Talvez E. B. Allaire tenha mesmo razão quando afirma que, por pressuporem a diferença numérica entre os relata, as relações espaciais não a podem explicar. Repare-se que dizer que as relações espaciais pressupõem uma diferença numérica entre os relata não é dizer que a mera existência dessas relações pressupõe que haja diversidade de particulares. A mera existência das relações espaciais não pressupõe seja o que for acerca dos particulares. As relações espaciais apenas pressupõem alguma coisa acerca dos particulares quando os relacionam. Por isso, estas relações, além de existirem, têm de compor o tecido da realidade, para formar a estrutura espacial que individua os particulares que nela estão integrados.

Convém notar que é bastante diferente dizer que as relações existem e dizer que relacionam estas ou aquelas coisas. A diferença é entre uma mera lista e uma afirmação. Para compreender melhor esta diferença, consideremos os seguintes cenários. (1) Num mundo possível existem apenas os particulares $A, B$ e $C$, e é verdade que $\mathrm{R} 1(\mathrm{~A}, \mathrm{~B}), \mathrm{R} 1(\mathrm{~A}, \mathrm{C})$ e $\mathrm{R} 2$ (B, C). (2) Noutro mundo possível existem os mesmos particulares e é verdade que $R 1(A, B), R 2(A, C)$ e $R 2(B, C)$. $A$ ideia é clara. Há uma diferença entre os dois mundos no que diz respeito àquilo que as relações $\mathrm{R} 1$ e $\mathrm{R} 2$ relacionam, sem haver qualquer diferença relativamente à sua existência. Num dos mundos, R1 é instanciada duas vezes e no outro é instanciada apenas uma vez. Num dos mundos, há apenas um par de particulares a instanciar R1 e no outro há dois. Mas as relações estão presentes em ambos os 
mundos. Por isso, existir não implica relacionar aquilo que as relações efetivamente relacionam ${ }^{12}$.

Ora, para as relações relacionarem particulares, é necessário que haja particulares e que estes, aos pares, triplos, ..., instanciem essas relações. De acordo com a Tese de Allaire, para uma relação espacial $n$-ádica relacionar o que quer que seja, tem de haver pelo menos $n$ coisas. O problema é que, de acordo com a proposta que estamos a considerar, é a própria relação que faz com que haja $n$ particulares dispostos a serem relacionados. Como podem então certas relações relacionar seja o que for se elas têm de relacionar coisas numericamente distintas e são as próprias relações as responsáveis pela existência dessas coisas numericamente distintas? Era um problema muito parecido com este, creio, que E. B. Allaire tinha em mente quando escreveu:
Que as relações pressupõem a diferença numérica entre as coisas que exemplificam a relação pode ser compreendido da seguinte forma. Representemos as coisas através dos caracteres não-relacionais nelas contidos, e sejam ' $\mathrm{A}$ ', ' $\mathrm{B}$ ', 'C', e por aí adiante, nomes de diferentes conjuntos de caracteres. (A diferença reside em um ou mais carac- teres.) Além disso, ' $E$ ' designa à-esquerda-de; e ' $E(-, \ldots)$ ' é a forma de representar o facto de que E é exemplificada. Dado que há coisas que têm os mesmos caracteres não-re- lacionais, podemos vir a encontrar esta representação 'E(A, A)'. Deste modo, teríamos de dizer que uma mesma coisa está à esquerda de si mesma. Mas não pretendemos dizer isso, pois, como sabemos, há uma coisa à esquerda da outra. Assim, ao representarmos que as coisas estão

\footnotetext{
12 Não pretendo aqui assumir que existem apenas os universais que são instanciados, nem a diferença entre uma lista e uma afirmação depende dessa suposição. Na verdade, se supusermos que qualquer universal possível existe em todos os mundos possíveis, independentemente de ser ou não instanciado, a diferença é ainda mais clara: as mesmas relações existem em todos os mundos possíveis, mas só em alguns deles é que relacionam o que quer que seja.
} 
espacialmente relacionadas, algo mais do que apenas caracteres e relações deve ser representado.

(Allaire 1965: 19)

Parece-me, no entanto, que um teórico aglomeracionista não pode ceder a esta objeção. A objeção baseia-se num princípio que a teoria aglomeracionista condena logo à partida: o princípio de que para um universal ser instanciado é necessário que haja uma coisa que o instancia e que essa instanciação seja um facto primitivo ${ }^{13}$. Ora, a base da teoria aglomeracionista é a negação da aplicação deste princípio ao caso dos universais monádicos. A instanciação de um universal monádico, na teoria aglomeracionista, não é um facto primitivo que envolve o universal e uma outra coisa, consistindo, em vez disso, no facto de o universal estar integrado num aglomerado de universais copresentes.

Mas por que razão havemos de rejeitar este princípio no caso dos universais monádicos e aceitá-lo no caso dos universais poliádicos? A razão para isso é que parece não haver outra alternativa. Para as relações serem instanciadas elas têm mesmo de relacionar diversas coisas, e, sendo este um facto primitivo, a existência dos relata não pode depender de estarem a ser relacionadas. Mas esta aparência é ilusória. Existe uma outra forma bastante natural de as relações serem instanciadas. Devemos admitir que as relações espaciais, a um nível primitivo, não têm de relacionar o que quer que seja. Podemos dizer em vez disso que, como os universais monádicos, a um nível primitivo as relações espaciais estão relacionadas com outros universais

13 Ou pelo menos que para que um universal U seja instanciado é necessário que haja uma coisa que instancie alguns universais $\mathrm{U}_{1}, \ldots$. , Un tais que a instanciação de U é superveniente à instanciação conjunta de $\mathrm{U}_{1}, \ldots$, Un e que a instanciação de $\mathrm{U}_{1}, \ldots, \mathrm{Un}$ por essa coisa seja um facto primitivo, A ideia é que existem universais mais básicos do que outros, sendo que os universais mais básicos que uma coisa instancia determinam se a coisa instancia ou não qualquer outro universal. Ou seja, uma coisa é completamente descrita pelos universais mais básicos que instancia. Só a instanciação destes universais é um facto primitivo. Por exemplo, suponhamos que existe o universal complexo esfericidade ou retangularidade. Basta que uma coisa instancie a esfericidade ou instancie a retangularidade para que instancie a esfericidade ou retangularidade. Por isso, instanciar a retangularidade ou esfericidade não é um facto primitivo acerca de uma coisa. No entanto, podemos, creio, ignorar estas complicações no presente contexto porque os universais que nos interessam - certas relações espaciais - têm de ser universais básicos se pretendermos que cumpram um papel individuador. 
através de uma relação de ordem superior análoga à relação de copresença - chamemos-lhe relação de conexão. Em vez de ser estabelecida entre universais monádicos, a relação de conexão é instanciada, em cada caso, por uma relação e vários universais monádicos.

\section{6-Conclusão}

Sendo assim, as várias relações espaciais entram no tecido da realidade, e formam conjuntamente uma estrutura, por estabelecerem a relação de conexão com pares, triplos, ..., de universais monádicos. Ao conectarem-se com universais monádicos, as relações espaciais formam necessariamente as coisas que vão ser os seus relata - estes são os pontos da estrutura. Em cada ponto encontramos uma pluralidade de universais monádicos copresentes, todos eles conectados com relações espaciais e outros universais monádicos copresentes. Os pontos podem ser identificados com os aglomerados dos universais monádicos que neles se encontram. Dada a natureza de certas relações espaciais, que pressupõem diferença numérica, cada ponto é numericamente diferente dos demais. Assim, há a possibilidade de aglomerados de universais numericamente distintos, porque a mesma pluralidade de universais pode ser encontrada em vários pontos da estrutura formada pelas relações espaciais.

Os pontos da estrutura são individuados em virtude de factos unicamente acerca de universais. Mais especificamente, são individuados pela maneira como as relações espaciais se conectam com universais monádicos. Identificando agora os particulares concretos com os pontos da estrutura, chegamos então a uma perspetiva em que pode haver particulares indiscerníveis sem haver particulares primitivos.

Por recorrer à Tese de Allaire, esta proposta exclui a possibilidade de uma coisa estar a uma certa distância de si própria. Assim, rejeita a existência quer de universais quer de aglomerados de universais que ocorrem repetidamente. Será que esta proposta nos impede por isso de aceitar que mundos possíveis simétricos como aquele descrito por M. Black são mundos sem particulares primitivos? Recordemos que a ideia de J. O'Leary-Hawthorne (1995) era que poderíamos acei- 
tar mundos desse género em que aglomerados de universais estão a uma certa distância de si próprios. Essa descrição tem de ser rejeitada, mas, com a noção de conexão, podemos perfeitamente descrever esses mundos simétricos sem particulares primitivos de que J. O'Leary-Hawthorne falava como mundos em que pluralidades de universais monádicos conectam-se com uma relação de distância e consigo próprios. Nesses mundos, segundo a hipótese que estamos a considerar, existem particulares indiscerníveis que emergem da conexão entre as relações espaciais e os universais monádicos, mas continua a ser um mundo sem particularidade primitiva.

Há ainda mais duas objeções a esta proposta. Uma delas é que as relações espaciais não são capazes de individuar particulares que não existem espacialmente. Parece pelo menos possível que tivesse havido coisas deste género, mesmo que não haja nenhuma no mundo atual. Um ego cartesiano, por exemplo, tem uma duração temporal, mas nenhuma localização espacial, e talvez não queiramos que uma teoria acerca da individuação dos particulares implique a impossibilidade de coisas como egos cartesianos. Parece, então, que os particulares não-espaciais têm de ser individuados unicamente pelos universais monádicos que os compõem. A teoria aglomeracionista clássica é, assim, verdadeira acerca destas entidades, e aplicado apenas a elas o princípio da identidade dos indiscerníveis é necessário. Esta consequência não deixa numa posição confortável o proponente da individuação por relações espaciais.

A outra objeção é que as relações espaciais não podem distinguir numericamente particulares que estão espacialmente desconectados. Suponhamos que, paralelamente ao nosso universo, há um universo indiscernível que não estabelece qualquer relação espacial com o nosso. As relações espaciais não podem explicar a diferença numérica entre os dois universos. Dizer que não existe esta possibilidade de dois universos paralelos indiscerníveis parece ser problemático devido ao facto de parecer possível haver dois universos espacialmente desconectados muito semelhantes, mas com uma diferença qualitativa mínima num dos seus habitantes. Estes dois universos poderiam ser numericamente distinguidos pelos universais que instanciam. Mas não parece aceitável dizer que é possível haver 
dois universos como estes e que não é possível haver dois universos qualitativamente semelhantes a estes em quase todos os aspetos à exceção de uma pequena diferença num dos seus habitantes. A única alternativa que me parece razoável seria negar que possa existir uma diversidade de universais desconectados. Talvez seja uma verdade necessária que qualquer particular tenha de estabelecer relações externas com todos os restantes. 
João Faria e Silva, 'Uma abordagem reducionista ao problema da identidade dos indiscerníveis',

Linguagem e ontologia: questões sobre conhecimento e agência / Language and Ontology:

Questions on Knowledge and Agency, Porto, FLUP, 2021, pp. 43-80, https://doi.org/10.21747/978-989-9082-05-2/ofaa4.

\section{REFERÊNCIAS}

Adams, R. M. (1979). 'Primitive Thisness and Primitive Identity'. The Journal of Philosophy, 76, pp. 5-26.

Allaire, E. B. (1963). 'Bare Particulars'. Philosophical Issues, 14, pp. 1-8.

Allaire, E. B. (1965). 'Another Look at Bare Particulars', Philosophical Studies, 16, pp. 16-21.

Armstrong, D. M. (1978). 'Are Particulars Reducible to Universals?', in Armstrong, D. M.,

Universals and Scientific Realism, vol. I: Nominalism and Realism. Cambridge: Cambridge

University Press, pp. 89-101.

Black, M. (1952). 'The Identity of Indiscernibles'. Mind, 61, pp. 153-164.

Casullo, A. (1984). 'The Contingent Identity of Particulars and Universals'. Mind, 93, pp. 527-541.

Casullo, A. (1988). 'A Fourth Version of the Bundle Theory'. Philosophical Studies, 54, pp. 125-139.

Della Rocca, M. (2005). 'Two Spheres, Twenty Spheres, and the Identity of Indiscernibles'.

Pacific Philosophical Quarterly, 86, pp. 480-492.

Demirli, S. (2010). 'Indiscernibility and Bundles in a Structure'. Philosophical Studies, 151, pp. 1-18.

Lewis, D. (1966). 'An Argument for the Identity Theory'. The Journal of Philosophy, 63, pp. 17-25.

Lewis, D. (1986). On the Plurality of Worlds. Oxford: Blackwell Publishers.

Loux, M. J. (2006). 'Concrete Particulars I: Substrata, Bundles and Substances', in Loux, M. J., Metaphysics: A Contemporary Introduction. New York: Routledge, pp. 84-120.

O’Leary-Hawthorne, J. (1995). ‘The Bundle Theory of Substance and the Identity of Indiscernibles'. Analysis, 55, pp. 191-196.

Quine, W. V. O. (1948). 'On What There Is'. Review of Metaphysics, 2 (5), pp. 21-38.

Rodriguez-Pereyra, G. (2004). 'The Bundle Theory is Compatible with Distinct but Indiscernible Particulars'. Analysis, 64, pp. 72-81.

Russell, B. (1940). 'Proper Names', in Russell, B., An Inquiry into Meaning and Truth. London: George Allen and Unwin, pp. 94-107.

Van Cleve, J. (1985). 'Three Versions of The Bundle Theory'. Philosophical Studies, 47, pp. 95-107. Van Cleve, J. (2009). 'bundle theory', in Kim, J., Sosa, S., Rosenkrantz G. S. (eds.), A Companion to Metaphysics. Oxford: Blackwell Publishers, pp. 161-164.

van Inwagen, P. (2011). 'Relational vs. Constituent Ontologies'. Philosophical Perspectives, 25, pp. 389-405.

Williams, D. C. (1953). 'On the Elements of Being I'. Review of Metaphysics, 7, pp. 3-18.

Zhang, R. (2018). ‘A New Universal Bundle Theory'. Philosophia, 46, pp. 473-486. 